\title{
SOCIO-CULTURAL PROFILE OF HIV PATIENTS ATTENDING A TEACHING HOSPITAL WITH RESPECT TO THEIR GENDER.
}

K. Valleswary, K.V. Sathyanarayana Murthy, S.V. Prashanthi, S.S. Pratap.

1. Professor \& H.O.D., Department. of Community Medicine, RIMS. Ongole.

2. Professor, Department. of Community, Medicine, Gandhi Medical College, Hyderabad

3. Senior Resident, Department. of Community, Medicine, Gandhi Medical College, Hyderabad

4. Assistant Professor, Department. of Community, Medicine, KIMS, Amalapuram.

\section{CORRESPONDING AUTHOR:}

Dr. K. Valleswary,

Professor \& H.O.D., Dept. of Community

Medicine, RIMS, Ongole.

E-mail: valleswary @yahoo.com

\begin{abstract}
BACKGROUND: HIV/AIDS is an important public health problem throughout the globe and in India in particular. Andhra Pradesh is a state in India with high prevalence of this disease. Aim: To assess the socio-cultural profile of HIV/AIDS patients attending the ICTC of a teaching hospital in Ongole, Andhra Pradesh for understanding the different dynamics associated with the disease which would be useful in designing the services for prevention of disease as well as care, support and treatment. MATERIAL AND METHODS: Institutional based cross sectional study was done on HIV/AIDS patients attending ICTC of RIMS, Ongole during the period $1^{\text {st }}$ June, 2011 to $30^{\text {th }}$ September, 2011 using questionnaire and interview method. The data collected was entered in Microsoft Excel sheet and analyzed using Epi Info 6 software. Chi Square test was done wherever applicable. RESULTS AND CONCLUSIONS: High risk behavior is noted among the males. Most of the women receive the infection from their spouse. Subjective perception of pressure among the patients is high. The results highlight the need to strengthen the Behavior Change Communication services in this region as well as the counseling services for the HIV/AIDS positive subjects. Further studies of this sort are recommended from other regions to have a better understanding of HIV/AIDS.
\end{abstract}

KEYWORDS: HIV/AIDS, Socio-cultural profile, teaching hospital, Andhra Pradesh

INTRODUCTION: India has the third largest number of people living with HIV/AIDS. Based on HIV Sentinel Surveillance 2008-09, it is estimated that India has an adult prevalence of 0.31 percent with 23.9 lakh people infected with HIV, of which, 39 percent(9.3 lakh) are female and 3.5 percent are children under 15 years. Among the states, Manipur has shown the highest estimated adult HIV prcvalcnce (1.40\%), followed by Andhra Pradesh (0.90\%), Mizoram (0.81\%), Nagaland (0.78\%), Karnataka (0.63\%) and Maharashtra (0.55\%), It is estimated that India had approximately 1.2 lakh new HIV infections in 2009 of which the six high prevalence states account for 39 percent of the eases. Children under 15 yrs account for 3.5 percent of all infections, while 83 percent are the in age group 15-49 years. The four high prevalence states of South India (Andhra Pradesh-5 lakhs, Maharashtra-4.2 lakhs, Karnataka-2.5 lakhs, Tamil Nadu-1.5 lakhs) account for 55 percent of all HIV infections in the country. The primary drivers of HIV epidemic in India are commercial female sex 
workers, unprotected sex between men who have sex with men, and injecting drug use. It is estimated that there are 12.63 lakh Female Sex Workers, 3.5 lakh Men who have Sex with Men with high risk behaviour and 1.86 lakh Injecting Drug Users in India. Sex work continues to act as the most important source of HIV infection in India due to the large size of clients who get infected from sex workers. Clients of sex workers further transmit HIV infection to general population particularly low risk women and Single Male Migrants constitute a significant proportion of clients of sex workers. ${ }^{1}$

The issues surrounding HIV/AIDS are deeply embedded in social and cultural beliefs, personal and private. The assessment of socio-cultural profile of HIV positive people is very important to understand the different dynamics associated with the disease. This is useful in designing the services for these patients in relation to care, support and treatment as well as for prevention of spread of disease to others. The present study is taken up to study the socio-cultural profile of HIV positive patients attending a teaching hospital at Ongole in Andhra Pradesh, which is one of the six high prevalence states in India.

AIM: To assess the socio-cultural profile of HIV/AIDS patients attending the ICTC of a teaching hospital in Ongole, Andhra Pradesh for understanding the different dynamics associated with the disease which would be useful in designing the services for prevention of disease as well as care, support and treatment.

MATERIAL \& METHODS: Two hundred and twenty nine patients above 15 years of age who had attended ICTC and confirmed to be HIV positive and are studied in a period of four months $\left(1^{\text {st }}\right.$ June, 2011 to $30^{\text {th }}$ September, 2011) in the teaching hospital at Ongole, Andhra Pradesh. This is a cross sectional study using the questionnaire and interview method. The age and gender is recorded along with literacy, income and region of residence. The patient is interviewed regarding alcohol consumption, pressure perceived in life along with parental support, if present. The marital particulars like age at marriage, sexual disharmony in marriage and the way the disease is first contracted from inside or from outside of marriage is ascertained. Analysis is done using the Epi Info 6 software. Chi Square test was done wherever applicable.

RESULTS: In this study, 229 subjects were interviewed during the study period. Out of these 229 subjects, 103 (45\%) were males and 126 (55\%) were females. A higher proportion of subjects aged less than 21 years were females, and a higher proportion of subjects aged 21 years or more were males. This difference was found to be statistically significant (chi square $=23.66, p=0.000$ ). Above 37 percent of the study subjects were illiterate and more than 67 percent of study subjects worked as laborers. Most of the study subjects were from below poverty line and majority resided in rural areas. About 17.5 percent study subjects consumed alcohol and most of them were males. Majority of the subjects who did not consume alcohol were females. This difference is found to be statistically significant (Yates corrected chi square $=51.48, \mathrm{p}=0.000$ ). More than half of the study subjects did not have parental support and majority of the study subjects perceived pressure in their lives because of their HIV positivity status. A total of 210 study subjects were married. 


\section{ORIGINAL ARTICLE}

Table no. 1: Selected socio-cultural factors in relation to gender of HIV patients

\begin{tabular}{|c|c|c|c|c|c|c|}
\hline \multicolumn{2}{|c|}{ Variable } & Males & Females & Total & Chi square & p-value \\
\hline \multirow{3}{*}{ Age } & $<21$ years & $15(21.1)$ & $56(78.9)$ & $71(31.0)$ & \multirow{3}{*}{23.66} & \multirow{3}{*}{0.000} \\
\hline & & & & & & \\
\hline & $21+$ years & 88 (55.7) & $70(44.3)$ & $158(69.0)$ & & \\
\hline \multirow{2}{*}{ Literacy } & Illiterate & $42(49.4)$ & $43(50.6)$ & $85(37.1)$ & \multirow{2}{*}{1.07} & \multirow{2}{*}{0.300} \\
\hline & Literate & $61(42.4)$ & $83(57.6)$ & $144(62.9)$ & & \\
\hline \multirow[b]{2}{*}{ Occupation } & Laborer & $65(42.2)$ & 89 (57.8) & $154(67.2)$ & \multirow[b]{2}{*}{1.46} & \multirow[b]{2}{*}{0.227} \\
\hline & $\begin{array}{l}\text { Sedentary job } \\
\text { or Housewife }\end{array}$ & $38(50.7)$ & 37 (49.3) & 75 (32.8) & & \\
\hline \multirow[b]{2}{*}{ Residence } & Rural & $84(42.4)$ & $114(57.6)$ & $198(86.5)$ & \multirow[b]{2}{*}{3.85} & \multirow[b]{2}{*}{0.049} \\
\hline & Urban & $19(61.3)$ & 12 (38.7) & 31 (13.5) & & \\
\hline \multirow[b]{2}{*}{$\begin{array}{l}\text { Economic } \\
\text { status }\end{array}$} & APL Card & $1(50.0)$ & $1(50.0)$ & $2(0.9)$ & \multirow{2}{*}{$\begin{array}{c}0.33 \\
\text { (Yates } \\
\text { Corrected) }\end{array}$} & \multirow[b]{2}{*}{0.568} \\
\hline & BPL Card & $102(44.9)$ & $125(55.1)$ & 227 (99.1) & & \\
\hline \multirow{2}{*}{$\begin{array}{c}\text { Alcohol } \\
\text { Consumption }\end{array}$} & Yes & $39(97.5)$ & $1(2.5)$ & $40(17.5)$ & \multirow{2}{*}{$\begin{array}{c}51.48 \\
\text { (Yates } \\
\text { Corrected) }\end{array}$} & \multirow{2}{*}{0.000} \\
\hline & No & $64(33.9)$ & $125(66.1)$ & $189(82.5)$ & & \\
\hline \multirow{2}{*}{$\begin{array}{l}\text { Parental } \\
\text { support }\end{array}$} & Yes & $44(41.5)$ & $62(78.5)$ & $106(46.3)$ & \multirow{2}{*}{0.96} & \multirow[b]{2}{*}{0.327} \\
\hline & No & $59(48.0)$ & $64(52.0)$ & 123 (53.7) & & \\
\hline \multirow{3}{*}{ Pressure in life } & Yes & 97 (44.9) & $119(55.1)$ & 216 (94.3) & \multirow[b]{2}{*}{0.01} & \multirow[b]{2}{*}{0.930} \\
\hline & No & $6(46.2)$ & $7(53.8)$ & $13(5.7)$ & & \\
\hline & Married & $92(43.8)$ & $118(56.2)$ & 210 (91.7) & \multirow[b]{2}{*}{1.40} & \multirow[b]{2}{*}{0.237} \\
\hline Marital status & Unmarried & 11 (57.9) & $8(42.1)$ & $19(8.3)$ & & \\
\hline
\end{tabular}


Further subsample analysis was done for married study subjects to study selected marriage-related factors. Out of the 210 married study subjects, 92 (43.8\%) were males and 118 (56.2\%) were females. A significantly higher proportion of female study subjects were married at an age less than recommended age for marriage (Chi square $=33.73, p=0.000$ ). About 30 percent of married study subjects reported sexual disharmony.

Table no.2: Selected marriage-related factors according to gender of HIV patients

\begin{tabular}{|c|c|c|c|c|c|c|}
\hline Variable & & $\begin{array}{l}\text { Male } \\
\text { n (\%) }\end{array}$ & $\begin{array}{l}\text { Female } \\
\text { n (\%) }\end{array}$ & $\begin{array}{l}\text { Total } \\
\text { n (\% of } 210)\end{array}$ & Chi Square & $\mathrm{p}$-value \\
\hline \multirow{2}{*}{$\begin{array}{l}\text { Age at } \\
\text { marriage }\end{array}$} & $\begin{array}{l}<\text { Recommend } \\
\text { ed age }\end{array}$ & 49 (31.8) & 105 (68.2) & $154(73.3)$ & \multirow{2}{*}{33.73} & \multirow{2}{*}{0.000} \\
\hline & $\begin{array}{l}\text { > Recommend } \\
\text { ed age }\end{array}$ & $43(76.8)$ & $13(23.2)$ & $56(26.7)$ & & \\
\hline \multirow{3}{*}{$\begin{array}{l}\text { Sexual } \\
\text { Disharmony }\end{array}$} & Yes & $24(38.7)$ & $38(61.3)$ & 62 (29.5) & \multirow{3}{*}{0.93} & \multirow{3}{*}{0.335} \\
\hline & & & & & & \\
\hline & No & $68(45.9)$ & $80(54.1)$ & 14 (70.5) & & \\
\hline
\end{tabular}

DISCUSSION: In the present study, 55 percent of the total HIV positive study subjects were females. In a study done elsewhere, it was reported that women accounted for a quarter of all HIV cases. ${ }^{2}$ Prevalence of HIV is more than double of it in the present study. In the present study, majority of the HIV positive patients resided in rural areas. Most of the study subjects also belonged to Below Poverty Line category. A study from Bangladesh also reported higher prevalence in rural areas and in poorer sections of the populations ..$^{3}$ In the present study, higher proportion of alcoholics were males. Consumption of alcohol is explained to be a risk of contracting HIV in a study by Purdie MP, Norri SJ et al. ${ }^{2}$ In the present study, perceived pressure and discrimination is reported in $21.9 \%$ of the subjects. Studies done elsewhere have also reported significant association of depression with HIV disease..$^{4,5}$

\section{CONCLUSIONS:}

- More than half of the study subjects who were HIV positive were female subjects.

- High proportion of alcohol consumption is seen in males which puts them at risk for other diseases also.

- A very high proportion of study subjects perceive pressure and hence there is a need for counseling services to be strengthened.

- Majority of married female subjects got married at an age less than that recommended There is a need to conduct similar studies from other regions also to get a better understanding of the disease and the associated dynamics.

\section{REFERENCES:}




\section{ORIGINAL ARTICLE}

1. National AIDS Control Organization. Annual Report 2010-2011.

2. Purdie MP, NorriS J et al. The effects of acute alcohol intoxication, partner risk level, and general intention to have unprotected sex on women's sexual decision making with a new partner. Exp Clin Psychopharmacol. 2011 Oct;19(5);378-88

3. Gani MS, Chowdhury AM, Nystrom L Urban-Rural and socioeconomic variations in the knowledge of STIs and AIDS among Bangladeshi adolescents. Asia Pac J Public Health 2011 Oct 5

4. Iliyasu Z, Abubakar IS et al. Post diagnosis reaction, perceived stigma and sexual behavior of HIV/AIDS patients attending Aminu Kano teaching hospital. Northern Nigeria. Niger $\mathrm{j}$ Med. 2011 Jan-Mar;20(l);135-43

5. Andrinopoulos K, Clum G et al. Health related quality of life and psychosocial correlates among HJV infected. AIDS Educ Prev. 2011 Aug; 23(4);367-81 